\section{Rozpylenia. \\ Marańskie montaże Leopolda Buczkowskiego}

Piotr Sadzik
Artykułpowstał

w ramach grantu NCN

"Fenomen maranizmu.

Żydowska tradycja ukryta

i nowoczesność" (UMO-

-2017/25/B/HS2/02901).

TEKSTY DRUGIE 2019, NR 4, S. 89-111

DOI: 10.18318/td.2019.4.5 | ORCID: 0000-0002-7897-7992

Qpośród kilku epizodów, które Leopold Buczkowski Obsadzał w roli scen pierwotnych swojego myślenia o literaturze, szczególnie jeden wydaje się zapowiadać większość przyszłych wyborów i strategii twórczych autora Czarnego potoku. Po latach pisarz tak wspominał swoją wizytę na pogorzelisku po zlikwidowanym właśnie przez nazistów obozie pracy dla ludności żydowskiej: "on się dopalał, góry trupów niedopalonych. Chodzę po zgliszczach, a między popiołami spalona biblioteka kahałowa. Niektóre książki jeszcze się tliły, a ja w strasznym lęku. I kiedy znalazłem się przy tych wypalonych książkach, zostałem jak zahipnotyzowany"1.

1 L. Buczkowski Dziennik wojenny, Wydawnictwo UWM, Olsztyn 2001, s. 168. Cytaty z książek Leopolda Buczkowskiego pochodzą z następujących wydań: Wszystko jest dialogiem, Ludowa Spółdzielnia Wydawnicza, Warszawa 1984 (dalej jako WJD); Proza żywa, Pomorze, Bydgoszcz 1986 (dalej jako PŻ); Żywe dialogi, Pomorze, Bydgoszcz 1989 (dalej jako ŻD); Kapiele w Lucca, PIW, Warszawa 1974 (dalej jako KL); Pierwsza świetność, Wydawnictwo Literackie, Kraków 1978.
Piotr Sadzik - doktorant w Instytucie Literatury Polskiej UW. Zajmuje się filozofią literatury w kontekście refleksji postsekularnej oraz myśli Jacques'a Derridy. Niebawem pod jego redakcją ukażą się dwa tomy zbiorowe: Widma Derridy (opracowane wspólnie z Agatą Bielik-Robson) oraz Imiona anomii. Literatura wobec doświadczenia stanu wyjątkowego. Kontakt: sadzikpiotr@gmail.com. 
To w tych upiornych okolicznościach, kiedy zwęglone zwłoki najdosłowniej mieszają się z pożeranym przez ogień papierem, Buczkowski znajdzie problematykę, z której przepracowywaniem będzie się mierzyć cała jego twórczość. Przy spopielonych resztkach żydowskiego świata zostanie więc w sposób jak najbardziej dosłowny. Trawiony archiwalną gorączką, w swoich przemieniających się często w lapidaria pracach, będzie bowiem gromadzić wyłowione z wojennej pożogi odpryski kultury, która stanowiła istotny kontekst jego dorastania ${ }^{2}$. Nie jest przy tym oczywiście żadną tajemnicą to, że będący bliskim świadkiem eksterminacji Żydów Buczkowski, nie tylko jako jeden z pierwszych postawi pytanie o warunki możliwości literatury po Zagładzie, ale również udzieli na nie jednej z najbardziej radykalnych odpowiedzi, domagając się od tej strony całkowitej redefinicji samego pojęcia literackości (ŻD, 64) ${ }^{3}$. Mimo jednak zupełnie zrozumiałych predylekcji komentatorów, by w roztrzaskanym języku tych książek widzieć zapis traumatycznych doświadczeń autora ${ }^{4}$, ponura diagnostyka historii jako Benjaminowskiego usypiska ruin nie jest tu punktem dojścia. Buczkowski wykona bowiem ekwilibrystyczny gest: spróbuje wydobyć ze świadczącego o dziejowej katastrofie rumowiska okruch zbawiennej nadziei, wyprowadzając ją z pogłosów samej tej tradycji, której pozornie całkowity rozpad jednocześnie rejestruje.

Warto jednak zacząć od innej uwagi ogólnej. Wzorcowy model kultury, który w oczach Buczkowskiego wyznaczałby też idealny kształt międzyludzkiej komunikacji, pisarz odnajdywał w galicyjskiej mozaice języków, kultur i religii. Zdążył być świadkiem ostatnich etapów jej istnienia, kiedy miejscową wspólnotę tworzyła plątanina relacji zawiązywanych przez m.in. Polaków, Ukraińców, Żydów, Rosjan, Czechów, Węgrów czy Rumunów (PŻ, 27).Zamiast jednak hołdowania nostalgizującej mitologii cekańskiego tygla, Buczkowskiego interesuje zarysowanie na podstawie tej wyjściowej sytuacji swojego doświadczenia wizji o zasięgu prawdziwie globalnym: „człowiek,

2 O archiwalnej obsesji Buczkowskiego szerzej w: P. Sadzik Wykoleić język, wykoleić historię. "Anarchiwum" Leopolda Buczkowskiego, "Konteksty” 2015 nr 3 (310), s. 86-97. Zob. też J. Derrida Goraczka archiwum: impresja freudowska, przeł. J. Momro, Wydawnictwo IBL PAN, Warszawa 2016.

3 Zob. np. S. Buryła Prawda mitu i literatury: o pisarstwie Tadeusza Borowskiego i Leopolda Buczkowskiego, Universitas, Kraków 2003, a także teksty z poświęconego pisarzowi monograficznego numeru czasopisma "Konteksty” 2015 nr 3 (310). 
który nie ma możliwości przejrzeć się w innej kulturze, jest cyborgiem. Humanizm staje się homunkulizmem. [...] Z monokultury biorą się nawet wszystkie nacjonalizmy, a właściwie mam na myśli fobie narodowe, ksenofobie. Kto dzisiaj chce być proksenosem?" (ŻD, 170).W ten sposób Buczkowski, formułując etykę sprzyjającą kontaktom z obcym (xénos), stanowczo podważa oczywiście iluzję tożsamościowej autarkii i homogeniczności. Wiemy skądinąd, że te ogólne uwagi znajdują swoje konkretne historyczne punkty odniesienia. W idiolekcie wychowanego w "polikulturze” i przekonaniu o „nadrzędności dialogu kultur” (ŻD, 170) Buczkowskiego, „homunkulus” jest bowiem określeniem nazisty (PŻ, 35). Pożądana przez pisarza „wielostrunowość" musiała zatem przywieść go do pochwały „mieszańca”. To właśnie za pomocą tego terminu zdefiniuje zresztą samego siebie (PŻ, 74): „w moich stronach było kilka nacji, przynajmniej cztery krwie były dominujące i te cztery mam w sobie. Czasem wydaje mi się, że one prowadzą we mnie ze sobą dialog" (ŻD, 170). Ta niezwykła wizja wewnętrznej polifonii kultur, które wprowadzają w podmiotowe "ja" nierozstrzygalną gmatwę, przenosi kategorię dialogu w całkowicie nowy wymiar.

W ostentacyjnej kontrze wobec fantazmatu tożsamościowej czystości, który na jego oczach doprowadził do niosącej miliony ofiar hekatomby, Buczkowski chętnie otwiera przestrzeń dla mariaży kultur, ufając, że wydobycie ich z monotonnej martwoty wiedzie jedynie poprzez ich zmieszanie. Swoimi tekstami stwarza więc też platformę dla bezustannych spotkań stale przeglądających się w sobie języków, gdzie polski bezustannie rozsadzany jest nie tylko wtrętami z ukraińskiego, rosyjskiego, niemieckiego, hebrajskiego czy jidysz, ale także to one same są bezustannie wywłaszczane za sprawą swych regionalnych odmian i idiolektów. Multilingwizm Buczkowskiego wytwarza tu „przedziwny melanż językowy” (PŻ, 36), „,wolapik” (PŻ, 66) będący jednak przestrzenią nie tyle nostalgicznego restytuowania spopielonej Galicji, ile stanowczo wychylonego w przyszłość uruchamiania tożsamościowej różnorodności w doświadczeniu samego czytelnika. Buczkowski chętnie wszczepia więc do polszczyzny obce jej idiomy, aktywizuje jej ukrytą wielojęzyczność, która rozbijając jakąkolwiek spójność i własność, sprawia, że teksty te nie tyle domagają się przekładu z polskiego na inne języki, ile raczej to sam język polski, w którym dokonuje się niekonkluzywny proces wewnętrznego przekładu, staje się obcy samemu sobie. Babeliczność tego pisarstwa, performatyzującego Derridiańską pochwałę wiecznego przekładu jako ciągłego dekomponowania jednego i ostatecznego sensu, stawałaby się więc w ten sposób formą strukturalnej dekolonizacji języka, z jego marzeniami o dominacji 
i hegemonii ${ }^{5}$ W toku tych nieskończonych koniunkcji i konfuzji języki infekują tu siebie nawzajem, pozwalają zostawiać na sobie ślady języka innego, a tym samym wyrywają stojące za nimi kultury z ich wsobnej izolacji. Kiedy więc Buczkowski, rozpoczynając jedną ze swoich płomiennych tyrad przeciwko ,jednoplemieńcom”, mówi o tym, jak bardzo brakuje mu Żydów, stwierdza: „to nie są tylko tęsknoty do świata, który umarł, bierze się to z moich filozoficznych założeń. Z hołdu dla dialogiczności kultur. Wszystko, co twórcze, wynika z rozmowy między odmiennymi kulturami, ze zderzenia inności. Nie cierpię jednostronności, monotonii. Moje ucho poszukuje polifoniczności" (PŻ, 197). Tożsamościowa kontaminacja, którą stale podtrzymuje już sama poetyka tekstów Buczkowskiego a która zostaje przez niego wyniesiona do rangi nadrzędnej i uniwersalnej zasady, właśnie w żydowskości odnajduje wszak swoją najpełniejszą realizację.

Intensywność i charakter kontaktów Buczkowskiego ze światem żydowskim były niewątpliwie dalekie od szablonu. Pisarz miałby wręcz wychować się „właściwie wśród mieszkańców getta” (PŻ, 115).To dzięki anonimowemu Żydowi („wspaniały filozof - ja mu dużo zawdzięczam”; PŻ, 115) miałby zyskać dostęp do myśli, która nigdy nie przestanie nawiedzać jego pisarstwa: „wyrastałem w nieistniejącej już obyczajowości, w głębokiej filozofii żydowskiego folkloru. Tam nauczyłem się tego, co nazywa się filozofowaniem" (PŻ, 239). Takie zdumiewające transmisje międzykulturowe, których niemało w biografii pisarza, doskonale uchwytuje podpowiedziana przez niego formuła, w której nawet identyfikacja z nieżydowskością odbywa się za pomocą ostentacyjnie „zjidyszyzowanego" słowa: „ja gojałech, ale Żyd mnie uczył”. Dodajmy, że również inicjacja w literaturę odbywa się tu pod znakiem relacji ze światem Żydów. Swoją twórczość Buczkowski zwykł najchętniej wywodzić od medycznego protokołu, który sporządził jako pomocnik lekarza Chaima Goldberga. To właśnie ten mieszkający z rodziną Buczkowskich pod jednym dachem przyjaciel Leopolda (ŻD, 11) miał też namówić go na literacki debiut (PŻ, 191).Szczególną rolę w nawiązywaniu kontaktów ze światem żydowskim Buczkowski przypisywał swojemu ojcu, który nie tylko miałby mieć wśród

5 Zob. np. fragment Materia z Kąpieli w Lucca, będący zapisem wielojęzycznego katalogu słów, które wdzierają się w przestrzeń wieży Babel, mieszając szyki jej budowniczym. Zob. KL, 69-73. Za znakomitą należy dlatego uznać uwagę Krystyny Miłobędzkiej o Buczkowskim jako "kolekcjonerze języków”, którego „wszechświat językowy” uniemożliwia wtłoczenie w ramy jakiegokolwiek słownika. J. Borowiec Szare światło. Rozmowy z Krystyną Miłobędzkq̨ i Andrzejem Falkiewiczem, Biuro Literackie, Wrocław 2009, s. 154.

6 L. Buczkowski Znakiem tego, dialogizujemy dalej..., s. 168. 
Żydów bliskich przyjaciół, ale wręcz jakoby umiał mówić w jidysz (ŻD, 39). To właśnie jemu pisarz zawdzięczałby też zdumiewającą, jak sam to określał, „inicjację talmudyczną" (ŻD, 89). Kiedy ojciec został zatrudniony do prac w miejscowej bóżnicy, swojemu synowi polecił jakoby pokryć freskami ściany budynku. Cały ten utkany z niesamowitych epizodów wywód, zdradzający też niemałą wiedzę autora o kulturze żydowskiej, Buczkowski uwieńczy nieoczekiwaną krajoznawczą przechwałką: „znałem zresztą synagogi całej Małopolski" (PŻ, 121). Wszystkie te zaskakujące powinowactwa nie sprowadzają się jednak wyłącznie do poziomu biograficznej anegdoty lub incydentalnych i lokalnych odwołań. Jak się wydaje, szczególnie pojmowana żydowskość jest tu wszak nie tyle elementem utraconej galicyjskiej różnorodności, której Buczkowski był pasjonatem, ile raczej dostarczycielką podstawowej ramy pojęciowej tej twórczości, a także najbardziej przekonującego języka pozwalającego na rewitalizację etyki dialogu.

Wyznaczającą jądro tej twórczości ideę dialogu Buczkowski wywiódł ze znalezionego wśród popiołów kahalnej biblioteki Sartora Resartusa, wczesnej książki Thomasa Carlyle’a. Właściwe jej „absolutne zdialogizowanie materii słowa" (WJD, 5) nie tylko uczyni z niej stały i uprzywilejowany punkt odniesienia twórczości Buczkowskiego, ale także podsufluje mu metodę twórczą, którą po modyfikacjach pisarz uzna za własną. Podejmując się jednak swojej akcji, w najdosłowniejszym sensie tego słowa, ratunkowej’, Buczkowski ocala przecież przed ogniem nie tyle konkretny egzemplarz książki, ile ideę, do której dostęp zyskuje za pośrednictwem zakrzywiającego, ale w tym zniekształceniu także ocalającego ją pryzmatu twórczości szkockiego pisarza. Wiemy bowiem skądinąd, że odnalezioną w ten sposób ideę dialogu uznawał za centralny element żydowskiej myśli religijnej: „gdy będziemy mówić o filozofii spotkania, znajdziemy się w kręgu spekulatywnej myśli biorącej się z doświadczenia osobowego judaizmu" (ŻD, 58). W tej sytuacji książka Carlyle'a występuje w roli zarazem kamuflażu i filtra, przez który w myślenie Buczkowskiego wsącza się idiom tradycji pozornie nieskończenie od niej odległej.

To kluczowe dla pisania Buczkowskiego doświadczenie warto powiązać z jeszcze jednym niezwykłym cytatem, w którym autor Sartora Resartusa zostaje skojarzony z sytuacją, w jakiej wraz z nastaniem nowoczesności znalazł się judaizm: „religijne rozpoznanie osoby boskiej jest w rzeczywistości

7 Buczkowski podczas okupacji miał działać w tajemniczym zespole "ratowania dorobku kulturalnego przed zagładą" (WJD, 161). 
mową o osobie ludzkiej. Carlyle pierwszy, niby to żartobliwie, zauważył, że w jego czasach nie było już prawdziwej teologii, bo znalazła ona sobie miejsce w modnych powieściach. Wiele lat później o literaturze teologicznej będzie się mówiło na przykładzie Prousta i Kafki. Otóż żywe źródła monoteizmu zaczęły wysychać, judaizm stawał się religią martwą" (ŻD, 59). Pozornie neutralny ton referowania o losach teologii w nowoczesności udanie skrywa tu trafną autodiagnozę. W książkach autora Czarnego potoku niemało przecież odprysków żydowskiej tradycji, które po spopielącej ją katastrofie rozpaczliwie szukają sobie schronienia. Co więcej, niezapowiedziane przejście z opowieści o teologii do diagnozy stanu, w jaki popadł judaizm, dość wyraźnie sugeruje, że to właśnie uniwersum myśli żydowskiej stanowiło dla pisarza przykład refleksji religijnej perse. Buczkowski jako mistrz niesygnalizowanego cytatu i praktyk nieustannego kamuflażu oczywiście nie odsłania tu jednak wszystkich kart, na skutek czego nie wskazuje też na źródło tych szczególnych uwag. Wydaje się jednak, że nietrudno je zlokalizować. Zarówno porządek argumentacji, jak i dobór mających ją wspierać autorów (Proust i Kafka, przy zamianie Dostojewskiego na Carlyle'a) wskazuje na to, że Buczkowski całkiem wiernie parafrazuje tu słynne uwagi Gershoma Scholema spisane przy okazji lektury Gwiazdy zbawienia Franza Rosenzweiga ${ }^{8}$. Zgodnie z tezą postawioną przez tego największego XX-wiecznego znawcę kabały wobec upadku i wyjałowienia oficjalnej teologii właściwa jej problematyka w dobie nowoczesności wywędrowała w inne obszary, znajdując schronienie w przestrzeni literatury. Pomysł ten wydaje się zasadny, pod warunkiem wszakże, że wprowadzi się do niego pewną drobną poprawkę. Jak przekonywał w dyskusji z Scholemem o dziele Kafki Walter Benjamin, wspomnianego schronu nie wolno bowiem uznawać za miejsce, gdzie teologia przetrwałaby w stanie nienaruszonym, w świętej postaci swojej pełnej obecności, tak samo jednak jak nie można widzieć w nim prostej mety dla migracji tego, co teologiczne. Wkraczając w żywioł literatury kwestie teologiczne ulegają bowiem nieodwracalnemu zniekształceniu, co rodzi „teologię nader dwuznaczną i rozbitą,

8 Taki trop potwierdzałaby sąsiadująca z tym fragmentem uwaga o plajcie filozofii "od Jonii do Jeny" (ŻD, 64), będąca oczywistym nawiązaniem do słynnej frazy Rosenzweiga z Gwiazdy zbawienia, gdzie podejmuje on próbę wyjścia poza słupy demarkacyjne filozofii i zaklęty krąg jej grecko-niemieckich haseł ku trwałej obecności żydowskiego Objawienia. Buczkowski jednoznacznie sugeruje swoją przynależność do grona tych, którzy znaleźli się na tropach postulowanego przez Rosenzweiga "nowego myślenia". G. Scholem Franz Rosenzweig i jego "Gwiazda zbawienia", przeł. M. Zawanowska, w: Żydzi i Niemcy, przeł. M. Zawanowska, A. Lipszyc, Pogranicze, Sejny 2006, s. 181-182. 
która zjawia się jedynie wraz z postępującym procesem pisania"’. Jednocześnie w podobny sposób załamuje jednak dykcję czysto świeckiego dyskursu, delikatnie naginając jego trajektorię ku pytaniom o status objawienia. To ostatnie przybiera jednak w takich warunkach postać bytu jeszcze bardziej mikrego niż ten, który opisywał Scholem, mówiąc o redukcji objawienia do jego poziomu zerowego. Dla Benjamina funkcjonuje ono już jedynie jako pogłoska o sobie samym, plotka nieuwierzytelniona żadną postacią stabilnej i pozytywnej obecności sacrum. Wir, który wytwarza zanikające objawienie, delikatnie przemieszcza jednak poszczególne elementy tekstu literackiego, czyniąc z tego, co teologiczne nigdy w pełni nieuobecnioną, ale decydującą siłę, która modeluje kształt pisarstwa. Dlatego - jak stwierdza Benjamin będące najbardziej dobitną manifestacją tego procesu dzieło Kafki jest jedynie "podobne do literatury"10, nie stanowi traktatu teologicznego, który szyfrowałby swoje religijne odniesienia, ale uznanie go za całkowicie niezależny od teologii obiekt estetyczny również byłoby wyrazem braku umiarkowania. Do wszystkich tych cennych ustaleń i pochodów korekt należałoby dodać jeszcze tę jedną: dzieła Buczkowskiego, przesunięte w stosunku do pisania Kafki o jedno pokolenie w mrok i także dlatego mierzące się z jeszcze mocniej wygaszonymi światłami teologii, poruszają się w jej przestrzeni tym bardziej po omacku. Zacierają maksymalnie samo swoje podobieństwo do literatury, już nie tylko teologia zostaje tu całkowicie rozłamana, ale wraz z nią podobnej transformacji podlega także literackość, która miała gwarantować jej azyl. Rejestrując dosłowne spopielenie żydowskiej tradycji, muszą więc eksponować samo to zerwanie pasa transmisyjnego, który odpowiadał za migrację treści teologicznych, a tym samym, by sparafrazować Benjamina, stają się niezbyt podobne do literatury, zaprzeczają „wszystkim konwencjom powieści poza tą, że powieść jest zbudowana ze słów"11. Jeśli więc Buczkowski przekonuje o swoich związkach z myślą żydowską, nie można widzieć w nim w żadnym razie jej prostego kontynuatora, ale raczej twórcę, który pisząc z miejsca drastycznego zerwania jej ciągłości, nie zasłania jej rozbicia, ale

9 A. Lipszyc Czas wiersza. Paul Celan i teologie literackie, Austeria, Kraków-Budapeszt 2015, s. 16.

10 W. Benjamin Konstelacje. Wybór tekstów, Wydawnictwo UJ, Kraków 2012, s. 238.

11 H. Bereza Zwiq̨zki naturalne: szkice naturalne, Ludowa Spółdzielnia Wydawnicza, Warszawa 1972, s. 148. Spostrzeżenie Berezy jest oczywiście trafne, pod warunkiem jednak, że uzupełnimy je uwagą o polimedialności twórczości Buczkowskiego, w której tekst literacki koegzystuje z pracami plastycznymi, a sam twórca wyrażał niezrealizowane pragnienie wydania książki wraz z dołączonymi do niej zapisami odgrywanej przez siebie samego żydowskiej muzyki. 
z pozostałych po niej ułomków swobodnie kleci nowe konstelacje, zarazem jednak dając jej niepowtarzalną szansę na przeżycie.

Radykalizując dlatego tezy Scholema, Buczkowski stwierdzi wprost, chyba nie bez cienia trafnej autoanalizy, że w dobie upadku oficjalnej teologii "reformatorami religii stali się poeci i epicy, a ich dzieła zastępują liturgię" $(\dot{Z} D, 41)$. Nie traćmy jednak z oczu faktu, że nie chodzi o prostą substytucję, w toku której nie zmieniałby się status samej teologii. Literatura wydaje się Buczkowskiemu osobliwym rodzajem liturgii, ponieważ inaczej niż jej konwencjonalna postać nie znajduje stabilizacji w stałej obecności objawienia, ale chybotliwie poszukuje sposobów realizacji wpisanego w nie programu etycznego, który jest już tylko niewyraźnie zasłyszaną pogłoską. Co więcej jednak, nawet tego zadania literatura nie może być pewna, ponieważ samo mówiące o nim rozpoznanie Scholema, traktuje się tu nie inaczej niż jako ledwie pogłoskę („będzie się mówiło”).W konsekwencji swoją relację z tym istniejącym-w-wygaszaniu i dlatego stale niedogaszonym objawieniem może sygnalizować jedynie półgębkiem i mimochodem, niejako przy okazji snucia pozornie odmiennych historii.

Do tezy o przeprowadzce teologii w uniwersum literatury Scholem powrócił po latach, zamykając swoje monumentalne studium o mistycyzmie żydowskim. Ilustrując kolejne etapy rozwoju tego nurtu, przytaczał zasłyszaną od Szmuela Agnona opowiastkę o następujących po sobie czterech pokoleniach rabinów. O ile pierwszy z nich, mierząc się z trudnym zadaniem, szedł do lasu, rozpalał ognisko i odmawiał modlitwy, o tyle ostatni, nigdzie się już nie ruszając, stwierdzał: „Nie możemy rozpalić ognia, nie znamy już odpowiedniej modlitwy, nie wiemy, gdzie znajduje się to miejsce w lesie, ale możemy o tym wszystkim opowiedzieć”. Oto - kwituje Scholem - „z całej tajemnicy pozostała w końcu tylko opowieść. To właśnie jest obecna sytuacja mistyki żydowskiej"12. Ta genialna w swojej prostocie opowiastka rejestruje więc dwojaki proces: ubywaniu zdolności nawiązywania bezpośredniego kontaktu z transcendencją towarzyszy tu przybieranie na wadze gestów, które z punktu widzenia sytuacji wyjściowej, o jakiej się tu opowiada, wydają się wprawdzie zupełnie podrzędne, to jednak one stają się jedynym depozytem przechowującym nitki łączące z tym, co teologiczne. Opowieść, która zastąpiła tajemnicę (czy wedle analogicznego schematu Buczkowskiego literatura, która pojawia się w miejsce liturgii), objawia się u końca procesu, który

12 G. Scholem Mistycyzm żydowski i jego główne kierunki, przeł. I. Kania, Aletheia, Warszawa 2007, s. 385 . 
choć w oczach ortodoksji uchodzi za degradację, otwiera nieprawdopodobną szansę na ożywianie treści skazanych na gruncie „właściwej” teologii na całkowitą martwotę. Umiejętność rozniecania ognia utracona w podanej przez Scholema opowieści jako pierwsza podczas transmisji treści teologicznych, u Buczkowskiego odgrywa już zupełnie inną rolę. Ogień, który był żywym medium tradycji, zostaje zastąpiony ogniem jako nośnikiem trawiącego ją do szczętu zniszczenia. Upiorny przypadek sprawił, że Buczkowski stąpa po żarzących się zgliszczach kahału w Sasowie, tym samym, w którym swoich nauk udzielał jeden z przedstawionych przez Scholema cadyków, mówiących właśnie o utraconej umiejętności wzniecania płomieni ${ }^{13}$. Jeśli jednak Mojżesz Lejb polecał w zamian za to zadowolić się zdolnością znajdowania miejsca w lesie, gdzie te niedostępne już nam obrzędy praktykowano, Buczkowski zjawia się na zgliszczach świata żydowskiego, jedyną jego placówkę odnajdując w pogłosach, które przeżywają jego śmierć. O ogniu, który trawi cały fragment o wizycie w Sasowie (dopalający się obóz, niedopalone trupy, zmieszana z popiołami spalona biblioteka, tlące się i powypalane książki), Buczkowski stara się zatem pomyśleć w sposób karkołomnie dialektyczny. Jedną ręką wyławia z pogorzeliska nadpalone kartki, ratując je przed całkowitym pochłonięciem przez niszczycielski ogień, drugą jednak ze strzępów tych montuje nowe konstelacje, jedyną pozostałość po zerwanym lineażu tradycji, któremu początek dał niedostępny już żywy płomień transcendencji. Wydzierając więc wojennemu ogniowi ostatnie nie do końca przez niego spopielone resztki żydowskiego świata, nie tylko rejestruje ich zniszczenie, ale także ocala świadectwa innego ognia, przeżywającego śmierć judaizmu żaru mesjańskiej obietnicy, która mogłaby zapobiec kataklizmom podobnym do tego, którego jest świadkiem.

Na ten ostatni wątek myślenia Buczkowskiego wskazuje absolutnie formacyjna rola, jaką przyznawał doświadczeniu Brodów („Brody mają swoje znaczenie, gdy chcę dociekać moich korzeni"; ŻD, 59). Choć w mieście miały niegdyś swoją siedzibę „rabinackie szkoły filozofów, znanych i cenionych na całym świecie" (ŻD, 10), to jednak, jak stwierdza Buczkowski, swoją świetność miały one już za sobą. Okoliczność ta wydaje się jednak pisarzowi wielką szansą: „świetne miasta dopiero wtedy naprawdę promienieją, gdy chylą się

13 Choć Buczkowski urodził się w pasie oddzielającym Wołyń od Podola, chętnie podkreślał własną "podolskość", identyfikując się tym samym z obszarem, który stanowił laboratorium najśmielszych i najbardziej radykalnych nurtów heretyckich wykwitłych z wnętrza judaizmu. P. Maciejko Wieloplemienny tłum: Jakub Frank i ruch frankistowski, 1755-1816, przeł. J. Chmielewski, Wydawnictwo w Podwórku, Gdańsk 2014, s. 29. 
ku upadkowi. Czy czułem to wszystko w rozpyleniu, w powietrzu Brodów?" $(\dot{Z} D, 59)$. Buczkowski zakłada tu więc, że dopiero schyłkowa i kryzysowa postać danej formacji kulturowej pozwala wydestylować jej żywe jądro, nieotorbione wreszcie przesłaniającymi je zbędnymi ceremoniałami oficjalnej i dlatego zmurszałej w martwocie doktryny. Trudno nie dostrzec korespondencji między opowieścią o chyleniu się Brodów ku upadkowi a tą o kryzysie tradycyjnego judaizmu. To na taką właśnie kryzysową sytuację starały się bowiem znaleźć odpowiedź kiełkujące w rodzinnych stronach Buczkowskiego najbardziej krnąbrne, heretyckie ruchy, takie jak sabataizm i frankizm, które ze względu na swoją przekorę wzbudzały wielkie zainteresowanie i sympatię pisarza: „nie chciej być mędrcem, chciej być kabalistą. [...] Opowiadałem ci o kabalistyce, czemu do niej sięgnąłem, czemu się nią zająłem. Dlaczego chcę być nazywany kabalistą” (ŻD, 65). Choć więc stwierdzał on, że: „Brody były ośrodkiem rabinistycznym zwalczającym frankizm, jako jeden z prądów mistycznych, kabalistycznych szerzących się na ziemiach polskich w okresie przed i po pierwszym rozbiorze" (ŻD, 59-60), to jednocześnie zachowywały także pamięć o obiecujących w oczach pisarza poróżnieniach, które wstrząsały żydowską wspólnotą (ŻD, 113) ${ }^{14}$. Pogłosy tego niezwykłego duchowego fermentu w rozkruszonej postaci dotrwały do czasów Buczkowskiego: „Coś $\mathrm{z}$ tego, co istniało, musiało ocaleć, choćby w postaci pyłu rozproszonego w powietrzu" (ŻD, 191).

Piękna metafora „rozpylenia”, którą posługuje się Buczkowski, sugeruje więc, że dopiero w kryzysowym momencie, kiedy doktryna osiąga stan sproszkowanej pylistości, zrywa wprawdzie z macierzystym środowiskiem, aby w zamian, skoro źródłowe otoczenie cechowała jedynie martwota, zyskać możliwość wnikania w niedostępne dotychczas dla siebie rewiry. Jedynie stale wystawiając się na kontrasygnatę, kontaminację i zniekształcenie, a więc wnikając w języki, które okazują jej niewierność i ją wykorzeniają, gwarantuje sobie przeżycie. Judaizm przestaje być w tych warunkach określoną religijną doktryną, ale uczestniczy w niezbędnych procesach życiowych jednostek, już się go nie celebruje, ale nim oddycha, a tym samym zupełnie najdosłowniej żyje się nim, jakkolwiek w toku tych inhalacji zostaje on umieszczony z daleka od świętych miejsc, w których starali się go schować przed profanami zbyt 
opiekuńczy rabini. Owo „rozpylenie” nie oczekiwało więc miażdżącej świat żydowski katastrofy, ale stanowiło stan ją wyprzedzający. Trzeba rozumieć je zatem w wielu aspektach przedrostka „roz-”. W Sasowie Buczkowski rozgarnia bowiem popioły, by wydobyć z nich pozostałe po myśli żydowskiej resztki, będące zarazem punktem jej maksymalnej intensyfikacji i kondensacji. Ta osobliwa żydowskość, ocalona przed ogniem zniszczenia, przeżyła już jednak także śmierć oficjalnego judaizmu („stawał się religią martwą"), którego rytuały całkowicie wygasiły rozpalającą ją iskrę i dopiero obecnie, w postaci widmowego rozpylenia, zwiększa jej swój zasięg, rozprzestrzeniając się w najróżniejszych i nieprzewidywalnych kierunkach.

Buczkowski rozgrywa zatem dwa modusy pylistości, gdzie jeden oznacza apokalipsę spopielającą żydowską tradycję, drugi zaś jest momentem jej przeżycia, możliwego dzięki ukradkowemu wnikaniu w tkanki innych języków ${ }^{15}$. Nie jest chyba przypadkiem, że ze zgliszcz kahalnej biblioteki Buczkowski nie ocala żadnych emblematów żydowskości, ale to, w czym uległa ona już przemieszczeniu i kontaminacji, a zarazem skompresowaniu i kondensacji. Jeśli więc tradycja ta zaczyna widmowo rezonować przez teksty Buczkowskiego, to nie w wyniku bezpośredniego kontaktu pisarza ze świętymi tekstami judaizmu, ale dzięki powieści, której sama obecność w kahałowej bibliotece mogłaby stanowić znak przemian dokonujących się w łonie żydowskiej wspólnoty.

Kończąc swój wywód o migracji treści teologicznych, które w dobie nowoczesności zostały wmieszane w żywioł literatury, Buczkowski stwierdza: „filozofię spotkania rozwijają Żydzi asymilowani, często ci, którzy przeszli na chrześcijaństwo, albo, jak Martin Buber, stali się indyferentni" (ŻD, 59). Nurt myślowy, z którym pisarz chętnie będzie się identyfikował, miałby więc jego zdaniem znajdować swoje źródła w różnych formach wyjścia z tradycyjnego judaizmu, które zarazem, jak sam zaświadcza, zachowywałyby po nim pamięć. Nie wydaje się przy tym okolicznością zupełnie obojętną to, że Buczkowski całkowicie wprost wpisze doświadczenie konwersji Żydów w dzieje swojej rodziny. Opowiada o tym oczywiście w trybie niepewnej pogłoski, w ramach której "mówiło się", że "podobno" przodkowie babki „to byli frankiści, ci którzy z judaizmu przeszli na katolicyzm" (PŻ, 25). Zasłyszana legenda o frankistowskim pochodzeniu rodziny inicjuje zainteresowanie okazywane przez Buczkowskiego żydowskim konwertytom. O tym, że jego wiedza w tym

15 A. Bielik-Robson Marański uniwersalizm. Benjamin, Derrida i Buck-Morss o kondycji uniwersalnego wygnania, przeł. P. Sadzik, "Etyka” (numer w przygotowaniu). 
zakresie wykraczała poza standardowe hasła, może świadczyć choćby kilkustronicowy ustęp Żywych dialogów, poświęcony detalicznemu omówieniu historii frankizmu (ŻD, 113-115) ${ }^{16}$.

To właśnie owej babce, rzekomej frankistce, Buczkowski przyznawał szczególną rangę w wykształceniu własnego światopoglądu: „wszystko zawdzięczam babce [...] przyznam się, że cała moja twórczość jest wyrazem stosunku do niej" (PŻ, 27). Nie tylko dlatego, że, co ważne w kontekście sytuacji judaizmu, który stał się opowieścią, babka stanowiła dla Buczkowskiego wzór doskonałego narratora (PŻ, 25) i to po niej miał on odziedziczyć „talent opowiadacza” (PŻ, 24). Ta mówiąca „po rusku” rzekoma Ormianka, która zobaczywszy w 1919 roku wojsko polskie, nie wiedziała, „co znaczy takie najczęściej używane przez żołnierzy słowo na $p e$ ” (PŻ, 78), idealnie nadawała się do roli wzorcowej figury tożsamościowego melanżu. Buczkowski uznawał jednak jej udział we własnym pisarstwie za dużo większy. Nie tyle bowiem wyznaczałaby ona dający się naśladować model różnorodności, ile byłaby raczej samą przyczyną rozszczepienia gmatwającego tożsamość pisarza. To ostatnie, uporczywie przez Buczkowskiego podtrzymywane, przybierałoby formę stałego wewnętrznego dialogu, który nie byłby możliwy bez tego, co pisarz nazywa wprost „nawiedzeniem” (ŻD, 5) : „obcuję ze swoją babką, która jest we mnie” (ŻD, 165); "noszę moją babkę zawsze w sobie, ona jest wciąż ze mną" (PŻ, 27). Zintrojektowany w wewnętrznej krypcie „ja" bliski zmarły zaburza jego topografię, stanowiąc depozyt inności w samym sercu podmiotu, niedające się zasymilować obce ciało" ${ }^{17}$ W ten sposób pobudzana i aktywizowana przez dobiegające z krypty wezwanie twórczość Buczkowskiego staje się zapisem brzuchomówienia, gdzie każde słowo cechuje niezbywalna dwoistość. Zachowując to widmowe zanadrze, Buczkowski staje się więc nieuchronnie spadkobiercą dziedzictwa, które przemienia jego pisarstwo w zestaw ciągle odmykających się kryptycznych depozytów, gdzie trzeba byłoby

16 Montażysta rozszczepienia, jakim jest Buczkowski, także tutaj nie porzuca swojego zadania. Obszernie cytuje zarówno wymierzone w żydowską ortodoksję tezy "przeciw talmudystom", jak i polemiczną wobec nich relację Bera Bolechowera, który uczestniczył po stronie rabinatu w mającej kluczowe znaczenie dla wyłonienia się ruchu frankistowskiego dyspucie Iwowskiej.

17 W takim kontekście pojęciem "krypty”, inspirowanym zresztą nieortodoksyjną myślą żydowską, posługuje się Derrida. Zob. J. Derrida Fora. „Kanciaste” słowa Nicolasa Abrahama i Márii Török, przeł. B. Brzezicka, „Teksty Drugie” 2016 nr 2, s. 122-168. 
nie tylko dostrzec zaszyfrowany dialog z babką, ale również samą zmarłą uznać za figurę nieujawnianej niemożliwości ostatecznego rozstrzygnięcia o statusie „ja”. Buczkowski nawiedzany spektralną obecnością babki, która stale domaga się rozmowy, takie dialogowanie ze zmarłymi, a „szczególnie dziadkami", skojarzy zresztą wprost z nieortodoksyjną tradycją żydowską (ŻD, 90). Przypomnijmy przy tym, że ta ostatnia jest przecież strukturalnie niejako spektralna, skoro gwarantuje przeżycie judaizmowi, który poza nią stawał się religią martwą.

Rozpisywana przez Buczkowskiego apologia poróżnienia, gdzie każda tożsamość podlega bezustannym kontaminacjom, nie oszczędza więc także samej żydowskości, która nie może być już homogeniczna, ale jest rozłamana, niejednolita i powaśniona. Frankizm, na który pisarz powołuje się przy tej okazji, nie stanowi bowiem jedynie imienia heretyckiej doktryny, ale, jak ujmuje to Adam Lipszyc, kryptonim „rozszczepieńczej” formuły podmiotowości ${ }^{18}$. Funkcjonując w obrębie kolejnych wspólnot, frankiści przekraczają ograniczenia jednoznacznych społecznych identyfikacji, dając miejsce trwale niedookreślonemu i wewnętrznie rozszczepionemu pojedynczemu bytowi. Frankizm byłby więc najbardziej emblematycznym, miejscowym wariantem maranizmu. Marani - zmuszeni do konwersji na chrześcijaństwo hiszpańscy i portugalscy Żydzi, którzy przechowali w sekrecie niejasną pamięć o swoim dziedzictwie, ani nie będąc już wyznawcami judaizmu, ani nie mieszcząc się w granicach chrześcijaństwa, a zarazem czerpiąc z tradycji $i$ jednego, $i$ drugiego, określali siebie przez permanentne nie-dość-przynależenie. To wewnętrzne marańskie rozszczepienie, w toku którego wykonuje się pracę niekonkluzywnego przekładu, wydaje się stanowić model dla szczególnej koncepcji dialogizowania, z jakim Buczkowski identyfikuje swoje myślenie. Trop ten wydaje się zasadny tym bardziej, że to właśnie z maranami pisarz skojarzy galicyjskich Żydów, wśród których dorastał, wiążąc ich rodowód właśnie z Półwyspem Iberyjskim (PŻ, 89). Co jeszcze bardziej niezwykłe, wyprzedzając rozpoznania Lipszyca, Buczkowski wprost nazywa siebie „rozszczepioną monadą”: „nie jestem pełną osobą, rozczepiłem się. Umysł podzielony" (ŻD, 62).

To cięcie przebiegające przez tożsamość podmiotu i uniemożliwiające jego udaną integrację, posiłkując się Rozczepionym ja prekursora alternatywnej psychiatrii, Ronalda Davida Lainga, pisarz skojarzy ze schizofrenią. Identyfikacja ze „schizoikiem” służy Buczkowskiemu do sformułowania koncepcji

18 A. Lipszyc Czerwone listy. Frankistowskie eseje o literaturze polskiej, Austeria, Kraków 2018. 
podmiotu, który oddziela wyrwa zarówno od samego siebie, jak i świata, w którym "nie czuje się dobrze zadomowiony" ${ }^{{ }^{\prime}}$. W tej sytuacji dążenie do uzyskania stanu monolitycznej podmiotowości, staranie o nadmierne zintegrowanie „ja” jest zaś próbą zasypania cięcia, które ma charakter na wskroś źródłowy: „z natury jest człowiek rozdwojony” (ŻD, 139). Jeśli więc dążenie do osiągnięcia stanu pogodzonej ze sobą, idealnie harmonijnej i wymazującej wszelkie poróżnienie podmiotowości wydaje się Buczkowskiemu aktem, przeciwko któremu musi zwrócić się z całą furią, jest tak dlatego, że takie działania „scalaczy, monofizytów, monologistów" pociągają za sobą wymazanie podmiotowego rozczepienia jako strukturalnej otwartości na ożywczą rozmowę (ŻD, 139). Wydaje się, że tę dokonaną przez Buczkowskiego pochwałę schizofrenii jako formy zbawiennego, podmiotowego rozszczepienia warto czytać w kontekście sygnalizowanych przez niego samego frankistowskich tropów własnego pisarstwa.

Pisząc o swoim ciągłym, rozbijającym integralność „ja” dialogowaniu $\mathrm{z}$ babką, rzekomą potomkinią frankistów, Buczkowski posługuje się wszak figurą „dwójducha w jednym ciele” (ŻD, 5). Dokładnie tą samą, której użyje w błyskotliwej interpretacji Don Kichota: „jak u Cervantesa, jest to jeden człowiek rozdzielony na dwie połowy, bo Don Kichot i Sanczo Pansa to jedna osoba. Oni są dwój-duchy w jednym ciele, rozczepieni z ich natury, a rozmowa tych dwu ludzi, to zapis dialogu wewnętrznego, który toczył w sobie biedny poborca podatkowy Cervantes" (ŻD, 138). Smaku temu fragmentowi dodaje i to, że jak stwierdza za chwilę Buczkowski, ta naturalna dyspozycja do rozczepienia jest udziałem jego samego („urodziłem się do przepołowienia w każdym zakresie"; ŻD, 139), jak również to, że w Kapielach w Lucca, powieści, której tytuł zaczerpnął od emblematycznie marańskiego autora, jakim był Heinrich Heine, Buczkowski skojarzy Cervantesa z ukrywającym się wygnańcem-Żydem (KL, 24) ${ }^{20}$.Trudno ustalić, na ile zabiegi takie były rezultatem doskonałej intuicji, a na ile rozeznania w najświeższych ówcześnie

19 Związek między kształtem doktryny religijnej a uwarunkowaniami psychicznymi śledził m.in. Scholem, pisząc o chorobie umysłowej Szabtaja Cwiego. Zob. G. Scholem Mistycyzm..., s. 320. Według Buczkowskiego z kolei matka zwykła określać go mianem „miszigyna”, oznaczającym w jidysz osobę szaloną (ŻD, 37).

Heine jako emblematyczna postać tradycji marańskiej pojawia się już w tekstach inicjujących filozoficzną refleksję nad tym zjawiskiem. Zob. H. Arendt Żyd jako parias: ukryta tradycja, przeł. P. Nowak, w: tejże Pisma żydowskie, Fundacja Augusta hrabiego Cieszkowskiego, Warszawa 2012. I. Deutscher The Non-Jewish Jew, Oxford University Press, London-New York-Toronto 1968. 
ustaleniach cervantesologów $w^{21}$. Archiwalne kwerendy skupione na biografii pisarza, a także liczne próby interpretacyjne, pozwoliły im na sformułowanie tezy o marańskim pochodzeniu Cervantesa, który w przygodach Don Kichota miałby szyfrować doświadczenie żydowskich konwertytów. W owładniętych ustawowo zadekretowaną ideą "czystości krwi" krajach Półwyspu Iberyjskiego przełomu XV i XVI stulecia, gdzie nowych wyznawców chrześcijaństwa nie tylko dyskryminowano, ale też brutalnie prześladowano, podejrzewając ich o potajemne sprzyjanie judaizmowi, żydowskość uznawano za niezmywalny stygmat czy raczej plamę, z hiszpańskiego „la mancha"22. Niewykluczone, że do niej właśnie czynił aluzję Cervantes, wywodząc genealogię swojego najsłynniejszego bohatera z regionu, którego nazwa była tożsama ze słowem oznaczającym owo szczególne znamię, co pozwala w „Don Kichocie z Manczy” czytać „Don Kichota z marańskiej plamy”. Cervantes jako jeden z nuevos cristianos uczestniczyłby więc „w dwóch językach, dwóch wiarach, dwóch kulturach, nie przynależąc w pełni do żadnej z nich", a będąc "Żydem z pochodzenia i Hiszpanem na podstawie prostego aktu chrztu"23, w opowieści o Don Kichocie nie opowiadałby, jak się to standardowo ujmuje, o nieumiejętności rozróżnienia między rzeczywistością a fantasmagorią, ale zapisywałby schizofreniczną tożsamość podmiotu marańskiego, rozpiętego między trzymaną w sekrecie dawną a wyjawianą w pełnym świetle dnia nową tożsamością.

Biorący podczas wojny udział w działalności konspiracyjnej Buczkowski był oczywiście szczególnie wyczulony na tego typu utajenia. Podobnie jak w przypadku historycznych maranów, którzy skryte praktykowanie judaizmu mogli przypłacić stosem, udana konspiracja jest w jego świecie dosłownie sprawą życia i śmierci. Identyfikowanie etnicznej przynależności jako stygmatu, który poddaje się eksterminacji, unicestwia bowiem kolejnych przyjaciół i bliskich pisarza. To właśnie w odpowiedzi na tę sytuację Buczkowski

21 Za punkt zwrotny dla takiej lektury Cervantesa należy uznać wydanie książki Dominique Aubier w 1966 roku. Zob. tejże Don Quichotte, prophète d'Israël, Robert Laffont, Paris 1966. O bohaterze Cervantesa jako "zamaskowanym Żydzie” zob. również: R. Reichelberg Don Quichotte ou le roman d'un juif masqué, Seuil, Paris 1999. Zestawienie i omówienie kluczowych prac poświęconych temu zagadnieniu znajduje się w: M. McGaha Is There a Hidden Jewish Meaning in Don Quixote?, "Cervantes: Bulletin of the Cervantes Society of America" 2004 vol. 24 no. 1, s. 173-188. 
pisze o konieczności wypracowania zbioru przebiegłych praktyk kryptycznych. Umiejętność postępowania podług „prawa mimikry” pisarz wyniósł podobno z domu, w czym oczywiście decydującą rolę miała odegrać babka: „nie wszystkie nacje jednakowo potrafią wyczuwać prawo mimikry. Moja babka umiała” (PŻ, 194).To rozpięcie osobliwie eliptycznego łącznika między „nacją” a „babką" każe przypuszczać, że trudną sztukę tożsamościowego kamuflażu i utrzymywania „ja” w sferze niejawności Buczkowski uznawał za charakterystyczny rys etnicznego pomieszania, którego babka była wzorcowym nosicielem. Wobec tkwiącego w doszczętnie zdefiniowanych tożsamościach otoczenia, utrzymywanie w ukryciu własnych rozszczepień zyskuje tu rangę niezbędnej strategii przeżycia: „kamuflaż obowiązuje w czasie napięć, bo nie wiadomo, gdzie wróg, gdzie przyjaciel. Uprawiaj kamuflaż, wszystkie zwierzęta kamuflują się, przybierają barwę ochronną, żeby upodobnić się do otoczenia (PŻ, 194). Marzenie o byciu nierozpoznanym czy nawet niewidzialnym (w Doryckim krużganku żydowscy partyzanci wspominają o traktacie Kycer-szeło, który miałby uczyć tej sztuki) powracać będzie u Buczkowskiego na dziesiątki sposobów, wprowadzając do jego książek postaci zbiega lub dezertera, a także tropiących go szpiegów, szpicli i śledczych. Co ważniejsze jednak, partyzanckie mylenie tropów, dezinformacja, potrzeba kamuflażu znajdują swoje przedłużenie w roli tekstowego konspiratora, który bierze na siebie zadanie podtrzymywania stanu niejawności, z czego czyni jeden z fundujących własne dzieło imperatywów („nie wolno ujawniać się”; WJ, 36). Błędem byłoby więc twierdzić, że dialog u Buczkowskiego ma coś z epifanicznej bezpośredniości myśli Levinasa. Ażeby dialog w ogóle był możliwy, musi zostawiać miejsce do działania, a z tego względu nie może być wyrazem pełnej i frontalnej ostentacji: „w rozmowie często ważniejsze jest to, co znajduje się między wierszami” (ŻD, 3), „wysyłam sygnały, może nawet szyfrowane sygnały" (PŻ, 29).

Wątek szyfrowanej tożsamości powróci (oczywiście doskonale zaszyfrowany) w zupełnie niezwykłej, a przywoływanej już relacji o malowaniu fresków w synagodze. Buczkowski opowiada, jak to wtajemniczony przez szamesa w niuanse programu ikonograficznego miałby na ścianach bóżnicy namalować historię Estery. O tym, że nie chodziło o zadanie neutralne, zaświadczy, mówiąc o silnych emocjach, jakie w nim ona wywołała („ja to przeżywałem bardzo"), gwałtownych na tyle, że po latach postanowił odtworzyć te "motywy z bóżniczych fresków” na płótnie. Warto przypomnieć, że biblijna postać Żydówki, która zostawszy królową Persji, ocaliła od zagłady swój naród, od samego początku odgrywała centralną 
rolę w religijności maranów ${ }^{24}$. Rozpoznawali w niej zapowiedź własnego doświadczenia, w którym jedynie przymusowa asymilacja cudzych, a dominujących wzorców kulturowych gwarantowała im przeżycie. Sprawdzała się więc również jako model marańskich strategii mimikry i kamuflażu, co zostawiło też swój ślad w maskaradach urządzanych przy okazji święta Purim, które upamiętniało tę biblijną opowieść. Przenosząc zaś doświadczenie żydowskości na poziom ściśle indywidualnych losów i wyborów, historia ta oddalała potrzebę nawiązywania relacji między jednostką a Bogiem, którego imię w Księdze Estery nie pojawia się ani razu, przenosząc religijność na grunt bliskiego Buczkowskiemu doświadczenia „osobowego judaizmu", gdzie kod teologiczny stanowi maskę dla opowieści o relacji z drugim człowiekiem. Wydaje się niemożliwe, żeby Buczkowski nie zdawał sobie przy tym sprawy z istnienia lokalnego wariantu tej biblijnej historii. Legenda o Esterce, żydowskiej ukochanej króla Kazimierza Wielkiego, stała się przecież bardzo żywotnym wątkiem, często przewijającym się zarówno w literaturze polskiej, jak i w tej pisanej w jidysz, a w ten sposób również miejscem aporetycznego przeplotu obydwu stojących za nią tradycji ${ }^{25}$. Choć więc Buczkowski stwierdza, że „to całe wyobrażenie legendy o Esterze jest bardzo z ducha żydowskiego" (ŻD, 89-9o), precyzyjniej byłoby stwierdzić, że mówi o klasycznej figurze podmiotu marańskiego, który wchodzi w obszar dominującej w danym miejscu kultury (perskiej, polskiej, chrześcijańskiej etc.), by nigdy do niej w pełni nie przynależeć, a nie będąc też już członkiem wspólnoty żydowskiej, pozostaje hybrydycznie rozpięty między różnymi tożsamościami, by stale odwlekać ich definitywne domknięcie.

Trudno przy tej okazji stracić z oczu obszerny zbiór autokomentarzy do dzieła Buczkowskiego, których zapisy złożyły się na trzy niejednolite pod względem formalnym tomy, Wszystko jest dialogiem, Proza żywa i Żywe dialogi. Kiedy inicjator powstania tej osobliwej serii, Zygmunt Trziszka, nazywa pomieszczone w niej opowieści „oracjami”, przeocza kwalifikację gatunkową zaproponowaną przez samego pisarza: „nie formułujmy ostatecznych wniosków, niech nasze zakończenia hagad nie zawierają łopatologicznej konkluzji" (ŻD, 5). Oto więc, poszukując wzorca komentarza do swojej działalności,

E. Marks Marrano as metaphor: The /ewish presence in French writing, Columbia University Press, New York 1996. sunków dwóch kultur i tradycji, przeł. M. Adamczyk-Garbowska, Oficyna Naukowa, Warszawa 2000. 
Buczkowski odwołuje się do podziału na dwa korpusy tekstów, które różniąc się od siebie, a zarazem uzupełniając, tworzą zręby doktryny judaizmu. Talmudyczna halacha będąca zbiorem normatywnych wykładni Pisma, poświadczonych autorytetem komentujących je rabinów zostaje tu bowiem przeciwstawiona hagadzie, żywiołowi pleniającej się narracji, swobodnych opowieści i anegdot, które jednocześnie luzują rygory prawnych kodyfikacji i oświetlają ich meandry. Zwróćmy uwagę, że rozróżnienie to idealnie odzwierciedla również drogę, jaką zdaniem Scholema przeszła w nowoczesności teologia, porzucająca bezpieczne pielesze doktrynalnej legislacji na rzecz zniekształcającego ją uniwersum praktyki literackiej.

Ten hagadyczny status wypowiedzi Buczkowskiego przejawia się tu w wymiarze zarówno tematycznym, jak i metateoretycznym. Jeśli chodzi o pierwszy, autor Doryckiego krużganka korzysta z midraszy, które nie tyle nawet cytuje, ile wszczepia ich obszerne fragmenty we własne teksty, co najpełniejszy wyraz przybierze w Prozie żywej, gdzie wmontowany zostaje kilkudziesięciostronicowy zapis szczegółowych regulacji dotyczących żydowskich obrzędów religijnych (Szulchan-Aruch), wypisów z midraszy (Midrasz Tanchuma) oraz mających charakter mądrościowych sentencji pouczeń etycznych autorstwa starożytnych rabinów (Pirke Awot; PŻ, 122-166). Jeszcze ciekawsze wydają się jednak konsekwencje, jakie Buczkowski wyciąga ze zidentyfikowania hagadycznego statusu swoich opowieści.

Jeśli żywioł niesfornej hagady odwleka domknięcie się halachicznego Prawa, oznacza to też, że uniemożliwia doktrynie przybranie definitywnego, obdarzonego ostatecznym i jednolitym znaczeniem kształtu. Sytuacja ta przepisana na specyfikę doby nowoczesności, gdzie literatura mierzy się już nie z obecnością transcendencji, ale ledwie z pogłoską o objawieniu, wiodłaby do wypracowania takiego modelu pisarstwa, które samo ostentacyjnie otwierałoby się na hagadyczną kontrasygnatę jako życiodajne zniekształcenie tekstu oryginalnego. W ten sposób wystawiałoby się na wyrastający z jego źródłowej niekompletności komentarz, który sam wewnętrznie zdestabilizowany, zgodnie z talmudyczną ideą lektury, wzywałby do niekończącego się procesu glosowania.

Z płonących zgliszcz potężnego niegdyś gmachu teologii Buczkowski ocalałby więc jego najważniejszy, a zarazem najkruchszy element, spakowany w przenośnej postaci destylat z doktryny, który można wynieść poza źródłowy kontekst i wmontować w całkowicie nowe, obce jej, lecz ożywiające ją konfiguracje myślowe. Tym widmowym sednem judaizmu, które zostaje po ogołoceniu go ze wszystkich ornamentów ortodoksji, byłoby zaś przekonanie 
o potrzebie wykroczenia poza jednostkową suwerenność jako hipostazę finalnie dookreślonego, monadycznie domkniętego i w konsekwencji całkowicie martwego sensu. Inspirowana tą ideą opowieść może zaś zdobyć się wyłącznie na coś tak efemerycznego, jak wytrwałe otwieranie przestrzeni dla samej możliwości spotkania, a zatem również kontaminacji „ja”, które wybawia interwencja innego głosu. Kruchość relacji i chęci jej nawiązywania byłaby może ostatnim przyczółkiem etyczności w świecie, w którym „karabin maszynowy rozerwał wszystkie stosunki między faktami" (PŚ, 168-169). Pisarstwo kierowałoby się ostatnim imperatywem, jaki pozostał z objawienia, nakazem stwarzania zaprzepaszczonej w dobie Zagłady szansy na spotkanie z innym, a w jego wyniku do jedynego wydarzenia godnego tego miana, a zatem sytuacji dialogu. Choć więc omawiając tę ideę, Buczkowski nazywa Bubera „sojusznikiem”, nie rezygnuje z dialogicznego poróżnienia, które każe mu porzucić pogodę chasydzkich opowiastek autora Ja i Ty. Skoro wszystkie wzorce narracyjne nie tylko splajtowały, ale zostały skompromitowane jako bierni świadkowie procesu, który doprowadził do Zagłady, wówczas wynajdywanie innych postaci literatury stanowiłoby właściwy gest etyczny.

Taki właśnie wymiar wydaje się tkwić w tekstowych praktykach Buczkowskiego. Sklejając zjawiska z różnych porządków czasowych, zderzając materiały o heterogenicznej proweniencji i przynależności gatunkowej, a wreszcie rozbijając językową i pojęciową spójność swoich książek, twórca otwiera je na przyjście czytelnika, bez którego interwencji nie byłoby już możliwe, zmienne i każdorazowo inne, wydarzenie tekstu. Pogłos judaizującej dialogiczności wnika tu w tkanki nowoczesnej estetyki, zabiegając o to, by awangardowy montaż ${ }^{26}$, jakim są w istocie prace Buczkowskiego, być może jedyne w polskiej kulturze literaturze powieści kubistyczne, uczynić maksymalnie otwartym na nadejście innego. W tych warunkach literacki eksperyment, wynajdywanie literatury po Zagładzie, wyrasta z etycznego impulsu, który ocalając specyficznie pojmowaną żydowskość, przeżywającą zarówno śmierć judaizmu, jak i unicestwienie wyznającej go wspólnoty, uchylałby furtkę dla „prokseniczności”, etyki sprzyjającej rozszczepiającemu

26 Uznając Buczkowskiego za rodzaj Benjaminowskiego kronikarza, zamiast pojęciem „kolażu”, które pojawiało się w analizach twórczości autora Kamienia w pieluszkach, posługuję się figurą "montażu", po którą sięgał w swojej refleksji nad zapisem doświadczenia historycznego niemiecko-żydowski eseista. Zob. R. Nycz Kolaż literacki. Przykład prozy Leopolda Buczkowskiego, w: Tekstowy świat. Poststrukturalizm a wiedza o literaturze, Universitas, Kraków 2000. A. Karpowicz Kolaż. Awangardowy gest kreacji. Themerson. Buczkowski. Białoszewski, Wydawnictwa UW, Warszawa 2007. 
„ja" zmieszaniu z obcym. Charakteryzująca to pisarstwo poetyka marańskiego montażu byłaby zresztą nie tylko próbą znalezienia tekstowego ekwiwalentu dla rozszczepionej tożsamości, ale także bodźcem aktywizującym tę podmiotową formułę w doświadczeniu samego czytelnika. Odpowiedzialnością za powodzenie dialogu obarczone są tu wszak obydwie strony komunikacji. Buczkowski nie tylko stara się osiągnąć absolutne zdialogizowanie własnego pisarstwa, ale również wzywa do tego, by „słuchać dialogicznie” (ŻD, 62), a zatem nie tyle autorytatywnie i ostatecznie złożyć połupane strzępy jego dzieł w nową i stabilną całość, ale montując na nowo te książki, same będące niczym innym niż montażem, podtrzymać,,roz-”, które decyduje o aporetycznym splocie dystansu i bliskości wpisanym w każdą „roz-mowę”,jak również o podmiotowym rozszczepieniu, bez którego rozmowa jako wystawienie na inność nie byłaby w ogóle możliwa: „kiedy mówię - jest nas dwóch, ale gdy słuchasz, czy was też jest dwóch? Jestem sam, choć jestem ja i ja [...] mnie jest dwóch" (ŻD, 62).W taki sposób pisarstwo to staje się być może jedynym miejscem, w którym wewnętrznie porozcinana, podlegająca bezustannym kontaminacjom wewnętrznie rozszczepiona i heterogeniczna podmiotowość marańska wyznacza wzorzec poetyki i zasadę organizującą cały program etyczno-literacki.

Przemieniając swoje teksty w katalogi połupanych słów, które pozostają wciąż do składania i klejenia przez hagadycznego montażystę, Buczkowski zajmowałby się więc nie tyle kumulowaniem skrawków przeszłości, ile, niczym wspomniany przez Derridę, niemożliwy „historyk obietnicy" ${ }^{27}$, tworzyłby archiwum wychylone w przyszłość czy raczej otwierające na samo nadejście nieprzewidywalnej przyszłości. Jeśli w swojej książce o „gorączce archiwum" filozof uwagę tę umieszcza w kontekście swojej identyfikacji z maranami, to właśnie dlatego, że to oni wydają się tu wyznaczać wzorzec działania, której stawką nie jest już judaizm, ale tkwiąca w nim, odśrodkowo rozsadzająca i przekraczająca jego ograniczenia żydowskość, nieredukowalna do jakiegokolwiek doświadczenia religijnego czy wiary w Boga. Tym zaś, co jako jedyne by ją definiowało, byłaby właśnie bezwarunkowa afirmacja przyszłości, przybierająca także postać maksymalnej otwartości tekstu-montażu: „bycie otwartym na przyszłość to bycie Żydem”.28.

W ten sposób postawa Buczkowskiego ustanawia jednak przestrzeń całkowicie nieprzewidywalnych tożsamościowych negocjacji, transferów

27 J. Derrida Gorq̨czka archiwum..., s. 106.

28 Tamże, s. 112. 
i kontaminacji. Czy nie będąc Żydem, ale zarazem nie mieszcząc się w ciasnych ramach zaprzeczenia tej tożsamości, nie chcąc utracić dialogicznej relacji ze szczególnie rozumianą żydowskością, która zarazem wcale go w pełni nie określa, Buczkowski nie podsuwa nam biografii niewyobrażalnej z punktu widzenia ekonomii kolektywnych podziałów i oswojonych scenariuszy polsko-żydowskich relacji? Zafascynowanego żydowską teologią zbieracza i „znawcy judaików”29, który dzięki takiemu przyzywającemu go stale dziedzictwu nie potrafi zdecydować się na żadną prostą etniczną identyfikację czy formę wspólnotowej przynależności. Twórcy zdobywającego się na nieprawdopodobną, szczelinową i chiazmatyczną tożsamość, którego najbliższy przyjaciel, Chaim Goldberg uznawany jest przez jego matkę za własne dziecko, którego przybraną babką jest Żydówka, niejaka Ruth Nussbaum (na pamiątkę której przydomek przyjmie jego brat ${ }^{30}$ ), który dedykuje Dorycki krużganek pamięci swoich „poległych braci”, co czyta się zwykle jako hołd oddany członkom rodziny zamordowanym przez ukraińskich nacjonalistów, nie uwzględniając faktu, że książka traktuje o żydowskich partyzantach, który wreszcie podpowiada zupełnie zdumiewający trop, mówiąc o swojej przynależności do jednego z oddziałów żydowskiego podziemia ${ }^{31}$.

Przede wszystkim jednak Buczkowski wydaje się znajdować w maranie uniwersalny model tożsamości, gdzie żydowskość nie jest już wcale rezultatem etnicznej przynależności, ale obietnicą podmiotowej otwartości, która zachowuje mglistą pamięć o zniekształconym judaizmie. Ten ostatni okazuje się wszak nie wyrazem wybraństwa jednego narodu, ale formułą powszechnej pochwały pojedynczości: „pobożni wszystkich narodów mają udział w życiu wiecznem. Każdego, który nie służy bożkom, należy uważać za Żyda, za wyznawcę religii żydowskiej. [...] Jest napisane: Oto jest nauka dla człowieka... Nie jest zaś napisane: Jest to nauka dla Izraelitów, kapłanów, lewitów"

29 W taki sposób Buczkowskiego określa w niezbadanej dotąd korespondencji z pisarzem, Salomon Łastik, autor monografii o polskich wymiarach haskali (Z dziejów oświecenia żydowskiego: ludzie i fakty, PIW, Warszawa 1961). Dział Rękopisów Muzeum Literatury w Warszawie, rkps. sygn. 1646, k. 36 . Z listu wynika, że Buczkowski wykazywał spore zainteresowanie Izraelem Axenfeldem, urodzonym na Podolu prozatorem i dramaturgiem, który pod koniec XVIII wieku przeszedł drogę od tradycyjnego judaizmu, przez fascynację chasydyzmem do przychylności dla haskali. Łastik wielokrotnie także spotykał się z Buczkowskim. Za informację tę dziękuję Tadeuszowi Buczkowskiemu, synowi pisarza.

H. Kirchner Pan Leopold. Rysunek z pamięci, w: Wspomnienia o Leopoldzie Buczkowskim, red. J. Tomkowski, Dom na Wsi, Ossa 2005, s. 78. 
(PŻ,144). Nie podkreślające ekskluzywizm jednego narodu wybraństwo, lecz drugie z fundamentalnych doświadczeń żydowskiej wspólnoty, wygnaństwo staje się tutaj kondycją uniwersalną: „wszyscy jesteśmy wygnańcami, a nasz świat jest Wygnańskim” (ŻD, 184). Imię „Izraela” nie nosiłaby już więc pojedyncza i określona etnicznie zbiorowość, ale „wszystkie miejsca i ludy, gotowe do tego, by rozpoznać się w owym przewidywaniu i w owym nakazie"32. Wygnanie jako kondycja uniwersalna nie wiąże się jednak wyłącznie z kryzysem, stwarza niepowtarzalną szansę dla tradycji, która wreszcie wysadzona ze swoich kolein podlega swobodnej i rozwiązłej „cytowalności”, przechodząc do „otwartego dostępu". Staje się odtąd znaczącą i rozpoznawalną dla „kaźdego, wszędzie, kiedykolwiek", wnikając w odległe od jej pierwotnego kontekstu konstelacje i jedynie za cenę tej zdrady, może produkować nowe konfiguracje myśli, a w konsekwencji przeżywać własną śmierć33.

Ta będąca sukcesywnie ponawianym wezwaniem do bycia "proksenosem" twórczość stanowi zatem dynamit wtykany w logikę koniecznych dookreśleń i segmentacji tożsamości. Buczkowski wyławia żydowskość z jej niedopalonych strzępów, by w zawrotnie dialektycznym ruchu przeciwstawić apokaliptycznemu ogniowi okupacyjnego zniszczenia, inny ogień, tlący się płomyk wciąż niewygaszonej teologicznej tradycji, która sprzyjałaby racjom wewnętrznie porozcinanych i niedomykalnych „ja”. Nie jest w żadnym razie jej prawowiernym kontynuatorem, ale kimś, kto jedynie oddychając nią, jej rozpylenie stara się przeciwstawić popiołom, które zostały po niemal całkowitej anihilacji żydowskiego świata. Nawet jeśli rozpylenie to, niczym samo objawienie, jak i rzekomy frankizm przodków Buczkowskiego, jest tylko transmisją trudnej do zweryfikowania i niewyraźnie zasłyszanej pogłoski. 


\section{Abstract}

\section{Piotr Sadzik}

INSTITUTE OF PHILOSOPHY AND SOCIOLOGY OF THE POLISH ACADEMY OF SCIENCES, UNIVERSITY OF WARSAW

Atomisation: Leopold Buczkowski's Marrano Montages

Sadzik explores the work of the Polish writer and visual artist Leopold Buczkowski (1905-1989) and its previously overlooked relationship to the philosophy of non-orthodox Judaism. Buczkowski found it so inspiring that he made it into the fundamental conceptual framework for organising his own writing and built his own ethical programme on it. What is more, he offers a brilliant diagnosis of the situation of Jewish theology in the modern era, conducting an encrypted dialogue with leading thinkers such as Gershom Scholem, Franz Rosenzweig or Martin Buber. Drawing on Derrida's work, Sadzik argues that there is a direct link between the Marrano formula of "splitting" subjectivity [rozszczepienie] postulated by Buczkowski and the montage poetics of this writing.

\section{Keywords}

Leopold Buczkowski, Marranism, Frankism, dialogue, montage 